\title{
Reflections on Anti-immigration Narratives and the Establishment of Global Apartheid
}

\author{
Yajaira Ceciliano-Navarro, Tanya Golash-Boza, and \\ Luis Rubén González Márquez
}

\section{APARTHEID IDEOLOGY: A PERSISTENT WORLD ORDER}

Although Apartheid in South Africa was dismantled in 1994 in the aftermath of massive national demonstrations and international pressure, the ideology of apartheid persists on a global scale. The global apartheid paradigm helps to explain global trends in the distribution of wealth and rights according to place of birth, race, and ethnicity, where some groups face more movement restrictions and criminalization than others. ${ }^{1}$ Some of the main principles of this paradigm are White racial superiority, persistent fear of national-identity loss, a desire to protect national territories, the war against immigrants, and the idea of free markets as the only avenue for prosperity. ${ }^{2}$ Those who subscribe to this ideology resort to creating laws, norms, and institutions that allow them to restrict people's movements, which at the same time distributes resources and inequalities along racial lines. Individuals placed at the bottom of this hierarchy are usually people of color who have limited geographic mobility due to visa restrictions. These people are often unable to enjoy fundamental human rights, such as employment, education, and housing. In contrast, White people, who are a numerical minority in the world, are placed at the top of this

This chapter is a revised translation of Y. Ceciliano and T. Golash-Boza, "Reflexiones sobre el Apartheid Global y la Migración," in C. Sandoval García (ed.), Puentes, no muros: contribuciones para una politica progresista en migraciones (México: Fundación Rosa Luxemburg and CLASCO, 2020), Pp. $25-47$.

1 See N. Sharma, "Anti-Trafficking Rhetoric and the Making of a Global Apartheid" (2005) 17(3) NWSA Journal 88-111; H. Van Houtum, "Human Blacklisting: The Global Apartheid of the EU's External Border Regime" (2010) 28(6) Environment and Planning D: Society and Space 957-976.

z F. V. Harrison, "Global Apartheid, Foreign Policy, and Human Rights" (2002) 4(3) Souls 48-68; A. H. Richmond and K. Valtonen, "Global Apartheid: Refugees, Racism, and the New World Order” (1994) 14(6) Refuge: Canada's Journal on Refugees 25-28. 
racial structure and enjoy the vast majority of existing wealth and privileges. ${ }^{3}$ This racial hierarchy promotes a world order characterized by racism and ethnocentrism. It operates at political, social, and geographic levels, and violates norms of justice, basic needs, human rights, democracy, and racial equality. ${ }^{4}$ The global apartheid ideology limits the opportunities of most people in the world. ${ }^{5}$

The global apartheid ideology is organized around narratives that criminalize immigrants and immigration. This criminalization justifies the establishment of different mechanisms that control and restrict immigrants' movements. People who have already crossed borders become vulnerable in diverse ways; due to fear, they do not access or request fundamental rights, and due to their status, they are more at risk for deportation. With restrictive immigration policies, unauthorized immigration tends to increase but the migratory process is more expensive and riskier. As if these immigration restrictions were not enough, this segregationist ideology also adopts subtle mechanisms of control, removal, and exploitation of migrants worldwide. These actions result in the preservation of wealth for a small minority.

The ideology of global apartheid fosters negative discourses and actions regarding the arrival of undocumented and poor immigrants from the Global South into the Global North. These actions can be described as a war against poor and undocumented immigrants. ${ }^{6}$ Given these circumstances, freedom of movement has transformed into an expensive and unsafe process - a privilege but not a right. One of the novelties of how this ideology operates today has been defined by Harrison as micro apartheid, where new territories and regions exhibit subtle racial and ethnic segregation mechanisms. ${ }^{7}$ In Europe, this trend continues to increase. France, Spain, and other European countries block the entrance of hundreds of migrants daily. ${ }^{8}$ At the same time, countries such as Chile and Israel have been adopting more subtle mechanisms for immigrants' removal. ${ }^{9}$ These "well-intentioned" mechanisms that help immigrants return to their home countries are part of this global trend. In this section, we analyze the modalities of reproduction of these discursive mechanisms and practices in different regions of the world.

3 See M. Omi and H. Winant, Racial Formation in the United States (New York and London: Routledge, 2014); J. R. Feagin and K. Ducey, Racist America: Roots, Current Realities, and Future Reparations (New York and London: Routledge, 2018).

4 G. Köhler, "The Three Meanings of Global Apartheid: Empirical, Normative, Existential" (1995) 20(3) Alternatives 403-413.

5 Harrison, "Global Apartheid, Foreign Policy, and Human Rights."

6 Van Houtum, "Human Blacklisting: The Global Apartheid of the EU's External Border Regime."

7 Harrison, "Global Apartheid, Foreign Policy, and Human Rights."

8 S. Alscher, "Knocking at the Doors of 'Fortress Europe': Migration and Border Control in Southern Spain and Eastern Poland," in Working Paper 126 (San Diego: The Center for Comparative Immigration Studies at University of California, San Diego, 2017).

9 S. Willen, Fighting for Dignity: Migrant Lives at Israel's Margins (Philadelphia: University of Pennsylvania Press, 2019). 


\section{Narratives of Immigrants as a Threat and Criminalization of Immigrants and Their Movements}

To achieve the criminalization of migrants, governments, media, and anti-migrant groups resort to narratives that portray them as inferior, unassimilable, and a threat to the country's stability, national identity, labor markets, or national security. ${ }^{10}$ The media shapes these public imaginaries, in which migrants are represented as violent and aggressive savages that must be stopped. ${ }^{11}$ Sharma argues there is a growing perceived need to protect migrant-receiving nations from "dangerous aliens." Once the portrayal of immigrants as a threat is invented, governments and other agents justify the creation of laws that prevent and punish immigrants' movements. The discursive representation of immigrants of color varies in different regions of the world, yet themes of immigrants as a problem and a threat are universally present. In the United States, for example, these populations have traditionally been depicted as a threat to national security and are considered violent and vicious. ${ }^{13}$ Hooghe and Dassonneville state that narratives in the United States "focused on racist resentment toward ethnic minority groups," mostly with regard to Mexicans. ${ }^{14}$ Otto Santa Ana argues that the United States' political narratives severely dehumanize immigrant workers. ${ }^{15}$ This dehumanization includes animalizing immigrants, which means portraying them as wild animals or savages that must be hunted by potent border predators of the state. For instance, along the border regions of the United States and Mexico, it is common to use terms like coyotes to refer to smugglers and pollos (chickens) to describe undocumented immigrants.

Immigrants are considered a burden in other regions and are often used as scapegoats for internal social problems such as unemployment or security. In Europe, migrants have been used by some extreme right-wing parties, whose leaders take advantage of growing discontent toward immigration policies and the influx of refugees. ${ }^{16}$ For these radical right-wing parties, immigrants threaten national identity

${ }^{10}$ M. Fennema, "Populist Parties of the Right," in J. Rydgren (ed.), Movements of Exclusion: Radical Right-Wing Populism in the Western World (New York: Nova Science Publishers, 2005), pp. 1-24; Richmond and Valtonen, "Global Apartheid: Refugees, Racism, and the New World Order."

${ }^{11}$ O. Santa Ana, "Like an Animal I Was Treated': Anti-Immigrant Metaphor in US Public Discourse" (1999) 10(2) Discourse \& Society 191-224.

12 Sharma, "Anti-Trafficking Rhetoric and the Making of a Global Apartheid."

${ }^{13}$ L. Chavez, The Latino Threat: Constructing Immigrants, Citizens, and the Nation (Santa Clara, CA: Stanford University Press, 2013).

${ }^{14}$ R. Dassonneville and M. Hooghe "The Noise of the Vote Recall Question: The Validity of the Vote Recall Question in Panel Studies in Belgium, Germany, and the Netherlands" (2017) 29 (2) International Journal of Public Opinion Research 316-338.

15 Santa Ana, "Like an Animal I Was Treated': Anti-immigrant Metaphor in US Public Discourse."

16 P. C. Gattinara, "Europeans, Shut the Borders! Anti-refugee Mobilisation in Italy and France," in D. Della Porta (ed.), Solidarity Mobilizations in the "Refugee Crisis": Contentious Moves 
(the "necessary" ethnic homogeneity) and also increase "competition" with locals for limited resources such as employment. In Europe, these narratives also permeate mobilizations in response to the refugee crisis. ${ }^{17}$ Richmond and Valtonen argue that wealthy and predominantly White countries have initiated a crusade to protect themselves from these perceived threats to safeguard their territories and privileged lifestyles. ${ }^{18}$ These discourses emphasize feelings of insecurity around immigrants, specifically the perceived threat they pose to the economy, society, racial purity, and national identity. ${ }^{19}$ For Fennema, one reason for the resurgence of these parties and narratives as well as their sympathizers is the growing perception of the dysfunction of national governments. ${ }^{20}$ Decision-making is viewed as having been centralized at the level of international organizations. Thus, among the public, there is a strong belief that national governments have lost credibility, leadership, and control over their borders, and these new far-right parties advocate for recovering state control over their countries. ${ }^{21}$

These ideologies have gained strength for different reasons. According to Richmond and Valtonen, these ideas grow due to the nostalgia evoked by a "simple life" - the idea that, in the past, the inhabitants of wealthy countries felt safer in more ethnically or racially homogeneous places. ${ }^{22}$ With the demographic transformations linked to global migration, these groups now feel that they are living in less secure and more "chaotic" conditions because of ethnic diversity. Other scholars posit that these criminalizing characterizations originate in fears over global terrorism that intensified after the attacks on New York and Washington, DC (9/11/o1), Madrid (3/11/04), and London ( $7 / 7 / 05)$. From such a perspective, all immigrants of color from poor countries are a threat that must be stopped and punished. ${ }^{23}$

\section{CONTROL AND RESTRICTION OF IMMIGRANTS' MOVEMENTS}

Governments attending the call to defend their nations against a perceived immigration threat rely on a series of structures and institutions to operate. Restrictive immigration laws constitute one of the most effective instruments for global apartheid's organization and application.

(Basingstoke: Palgrave Macmillan 2018), pp. 271-297. Dassonneville and Hooghe, "The Noise of the Vote Recall Question"; Fennema, "Populist Parties of the Right."

${ }_{17}^{17}$ Gattinara, "Europeans, Shut the Borders! Anti-refugee Mobilisation in Italy and France."

18 Richmond and Valtonen, "Global Apartheid: Refugees, Racism, and the New World Order."

19 Rydgren, Movements of Exclusion.

20 Fennema, "Populist Parties of the Right."

${ }^{21}$ Ibid.; C. M. Pied, "Ethnography and the Making of "The People': Uncovering Conservative Populist Politics in the United States" (2019) 78(3) American Journal of Economics and Sociology $761-786$.

${ }^{22}$ Richmond and Valtonen, "Global Apartheid: Refugees, Racism, and the New World Order."

${ }^{23}$ See Sharma, "Anti-trafficking Rhetoric and the Making of a Global Apartheid." See also Van Houtum, "Human Blacklisting: The Global Apartheid of the EU's External Border Regime." 


\section{Immigration Restriction and Immigrants' Control in the United States}

The United States was a sovereign nation for more than a century before immigration became a political issue. The first major piece of legislation on immigration was the Chinese Exclusion Act of 1882. This Act set the bar for entry into the country and had an openly racist frame directed toward a specific group: Chinese workers. By excluding members of this group based on class and race, the Chinese Exclusion Act paved the way for the immigration policies of the twentieth century. ${ }^{24}$ Although repealed in 1943 , the judicial decisions derived from the Chinese Exclusion Act still shape current legal approaches to immigration. The second relevant moment in immigration legislation was the Asian Exclusion Act of 1924, which expanded the regulations of the Chinese Exclusion Act and prohibited most immigration from Asia into the United States. ${ }^{25}$

These restrictive laws were repealed in 1965 with the passage of the Hart-Celler Act, which set an annual quota of 20,000 immigrants from each country of the world. This act changed the face of migration to the United States - from primarily European to increasingly Asian and Latin American. In this context of multiethnic migration, the United States began to pass new laws restricting the rights of migrants. The 1996 Antiterrorism and Effective Death Penalty Act (AEDPA) and the Illegal Immigration Reform and Immigrant Responsibility Act (IIRIRA) eliminated judicial review for some deportation orders and established mandatory detention for a significant number of non-citizens. ${ }^{26}$ They also allowed for the use of secret evidence in specific cases. Some of the most damaging consequences of these laws are the deportations of legal permanent residents. Under IIRIRA, if permanent legal residents are found guilty of "aggravated felonies," they face mandatory deportation. Relatively minor crimes such as shoplifting or drug possession could lead to mandatory deportation for long-term residents. ${ }^{27}$

After these laws were implemented, immigrants from Latin America and the Caribbean became more likely to be deported. The punitive and severe 1996 regulations disproportionately affect people of color. Kevin Johnson argues that, since the majority of immigrant populations living in the United States are minorities of color, the differential treatment toward non-citizens corresponds to legal practices that amount to racial discrimination. ${ }^{28}$ These practices have created an environment of tension and fear within Latino communities. ${ }^{29}$

24 Y. Le Espiritu, Asian American Panethnicity: Bridging Institutions and Identities (Philadelphia, PA: Temple University Press, 1992).

25 Ibid.

${ }_{26}$ T. Golash-Boza, Immigration Nation: Raids, Detentions, and Deportations in Post-9/11 America (London and New York: Taylor \& Francis, 2012).

27 Ibid.

${ }^{28}$ K. Johnson, "Racial Profiling after September 11: The Department of Justice's 2003 Guidelines" (2004) 50 Loyola Law Review $67-87$ at 67.

29 M. H. Lopez and S. Minushkin, 2008 National Survey of Latinos: Hispanic Voter Attitudes (Washington, DC: Pew Hispanic Center, 2008). 
The ideology of global apartheid was further strengthened with President Trump's election. He campaigned for the presidency primarily on the slogan "Build the Wall." Although there has long been a physical structure separating the United States from Mexico, this slogan itself is harmful to migrants as it implies that Mexicans pose a threat to the United States. On the campaign trail and as president, Trump has continued to take openly anti-immigrant positions. In several speeches, President Trump has portrayed immigrants as a threat by suggesting they are violent, criminal, and dangerous people. ${ }^{30}$ These anti-immigrant narratives, accompanied by a series of legislative decrees have led to the removal of thousands of immigrants and the expansion of immigration bans to more countries.

\section{US Immigration Policy and the Southern Border}

The ideology of global apartheid was challenged by the recent "Migrant Caravan" (or "Caravan for Life"), which began in 2018 in San Pedro Sula, Honduras. This caravan was formed by Salvadoran, Honduran, and Guatemalan migrants who escaped the economic deprivation and violence of their countries. According to different reports, the caravan reached in some moments 17,000 people. ${ }^{31}$ However, official data confirms that only five thousand of them reached the northern border of Mexico. On their way, Guatemala and Mexico closed their borders in response to pressure from the US government. However, this migratory event marked a milestone since it was not the traditional clandestine migration; the caravan was visible, massive, and filmed live in broad daylight. The caravan challenged and confronted classic actors in migration processes such as traffickers, governments, and NGOs. The migrant caravan reconfigured conventional ideas of clandestine migration. It also reconfigured territories, particularly for Mexico, which has traditionally been a migrant transit country and, on this occasion, became a "barred" country. ${ }^{22}$

\section{Immigration Restriction and Control of Immigrants in Europe}

European nations have also taken radical measures to keep people from poor countries out of their territories. ${ }^{33}$ These measures have been supported by rightwing governments, parties, and anti-immigrant discourses favoring increased restrictions on African migrants. For van Houtum, this has been manifested significantly in the reinforcement of borders and territorial limits: “[T]he European Union (E.U.)

30 Pied, "Ethnography and the Making of "The People."

$3^{1}$ A. Varela, "México, de “frontera vertical' a 'pais tapón.' Migrantes, deportados, retornados, desplazados internos y solicitantes de asilo en Mexico" (2019) 14(27) Iberoforum. Revista de Ciencias Sociales de la Universidad Iberoamericana 49-76.

32 Ibid.

33 J. Scott, "Hungarian Border Politics as an Anti-Politics of the European Union" (2020) 25(3) Geopolitics 658-677. 
has composed a so-called 'white' Schengen list, and a 'black' Schengen list and the white list represents the countries whose citizens do not need to apply for a visa for a visitor transit in Schengen countries."34 These lists indicate who is welcome (Whites) and who is not welcome (non-Whites) in Europe. This trend has continued in Europe after the migration crisis experienced in 2015. Many countries closed their borders in 2015 when more than a million migrants and refugees from Syria tried to reach the continent. Conflicts arose due to the different responses of each country to this migration crisis. While countries like Slovenia and Croatia closed their borders, others like Germany opened their borders and received a large number of refugees. Germany's attitude, described as generous, has been recognized internationally; however, it has sparked conflicts within the European community. Immigration is still a subject of controversy and contentious responses by European countries. ${ }^{35}$

Other expressions of this paradigm are present in different countries in Europe. For example, the migrant detention camp operating on the island of Lesvos, Greece, is a human rights crisis. Media have reported that thousands of migrants from various countries are stranded in Lesvos. Due to political decisions in different European countries, these migrants have been unable to continue their journey to Europe. The situation has become unsustainable not only for stranded migrants but also for the island's inhabitants. ${ }^{36}$

Denmark, a country where immigration was not previously present in the political agenda, has proposed similar initiatives designed to isolate immigrants. ${ }^{37}$ Liberal parties have discussed sending "undesirable" immigrants to the small islet of Lindhom (in the Baltic Sea), with barely any infrastructure. According to a report by El País, these immigrants would be required by law to leave the Scandinavian Kingdom. ${ }^{3}$ The Minister of Immigration, Inger Støjbeg, who is from the liberal party Venstre, declared on Facebook: "They are not welcome to Denmark and, they have to know it!"39 As reported by El País, this is just one among more than one hundred measures the Danish government has taken against immigrants. ${ }^{4^{\circ}}$ As van Houtum affirms, "with the construction of a gated island of wealth, and with the

34 Van Houtum, "Human Blacklisting: The Global Apartheid of the EU's External Border Regime," p. 936.

35 C. Kroet and B. Surk, "Slovenia, Croatia Close Borders to Migrants," Politico, March 9, 2016, www.politico.eu/article/slovenia-croatia-close-borders-to-migrants-refugees-serbia-macedoniaeu-deal-turkey/.

$3^{6}$ A. Afouxenidis et al., "Dealing with a Humanitarian Crisis: Refugees on the Eastern EU Border of the Island of Lesvos" (2012)12(1) Journal of Applied Security Research 7-39.

37 T. Bjørklund and G. A. Jørgen, "Anti-Immigration Parties in Denmark and Norway: The Progress Parties and the Danish People's Party," in M. Schain et al. (eds.), Shadows over Europe: The Development and Impact of the Extreme Right in Western Europe (New York: Palgrave Macmillan, 2002), pp. 107-136.

$3^{8}$ B. Dominguez Cebrian, “Dinamarca: Una isla para desterrar inmigrantes," El Pais, January 17, 2019, https:/elpais.com/internacional/2019/o1/17/actualidad/1547719266_874449.html.

39 Ibid.

$4^{\circ}$ Ibid. 
conscious denial of regular access to citizens from 135 countries, the E.U. widens the gap globally and regulates mortality of people on a global scale." ${ }^{41}$ All these restrictions mean that immigrants are increasingly vulnerable during the migration process and also when they are in the destination country, as described in the next section.

\section{THE CREATION OF MIGRANT VULNERABILITY}

Restrictive border policies make migrants more vulnerable both during the migration process and after their arrival in the country of destination. In the context of extreme global inequality, migration is the best and perhaps even the only choice to achieve a decent standard of living for a wide range of groups. ${ }^{42}$ Most people in impoverished conditions do not have the option of legally moving to a wealthier country. When they decide to migrate illegally, they become vulnerable to danger in the migration process as well as after arriving in the host country.

\section{Vulnerability in the Immigration Process}

When people choose to migrate despite legal restrictions against doing so, they are resisting "the territorial confining and material deprivations which the system of global apartheid imposes on them." 43 In this process, Spener argues, "migrants face a wide variety of forms of personal, structural and cultural violence." 44 For example, migrants from Senegal travel in rickety boats across the Strait of Gibraltar to enter Europe through Spain. As reported by the United Nations High Commissioner for Refugees (UNHCR), in 2016, more than 5,000 migrants died or disappeared in the Mediterranean Sea. ${ }^{45}$ Other NGOs say the number of deaths could be more than $13,000.4^{4}$ Additionally, there is evidence of at least 20,000 people trying to reach Europe who died in the Mediterranean Sea in the past two decades; meanwhile, from 2000 to 2013 , the number of immigrant deaths among those trying to reach Australia is approximately $1,500 .{ }^{47}$

${ }^{41}$ Van Houtum, "Human Blacklisting: The Global Apartheid of the EU's External Border Regime," p. 968.

$4^{2}$ J. H. Carens, "Who Belongs? Theoretical and Legal Questions about Birthright Citizenship in the United States" (1987) 37 University of Toronto Law Journal $413-443$ at 413.

43 D. Spener, "El apartheid global, el coyotaje y el discurso de la migracion clandestina: Distinciones entre violencia personal, estructural y cultural" (2008) 10 Migracion y desarrollo $127-156$.

44 Ibid. at 138 .

45 United Nations High Commissioner for Refugees, Global Trends: Forced Displacement in 2016 (Geneva: UNHCR 2016).

${ }^{6} 6$ Van Houtum, "Human Blacklisting: The Global Apartheid of the EU's External Border Regime."

47 Köhler, "The Three Meanings of Global Apartheid: Empirical, Normative, Existential," pp. 403-413; J. M. Loyd, "Carceral Citizenship in an Age of Global Apartheid" (2011) 30(3) Geography 118-128. 
In August 2010, Mexican authorities discovered the bodies of fifty-eight men and fourteen women who were murdered and piled in the small room of a ranch near the city of Matamoros, which borders the United States (in a dark irony, the city name literally means "kill moors"). The dead migrants included people from Brazil, Ecuador, Guatemala, and other countries. Although no one has been convicted for their murders, authorities suspect Los Zetas - a paramilitary criminal organization from Mexico - were the perpetrators. The murdered migrants probably refused to comply with the organization's demands to become hitmen and drug smugglers or could not afford an extortion payment. Human rights organizations estimated that 20,000 immigrants are kidnapped every year in the journey to the United States from Latin America. ${ }^{4}$ A significant number of Guatemalan and Brazilian immigrants report that traveling through Mexico was the most dangerous part of their journey. ${ }^{49}$ This journey is particularly unsafe for women and children: as published by Amnesty International, six of every ten Central American women and girls are victims of sexual violence during their journey through Mexico. ${ }^{50}$ The range of risks involved in this stage of the journey is a direct consequence of restrictive migration policies.

Nevertheless, despite all the risks and the new scenarios of hypervigilance, immigrants continue their odyssey; as van Houtum states "they adapt to the new rules, invent personalities, disidentify themselves by throwing away their papers or even crudely erase their fingerprints, that is, immigrants multiply and constantly build in new liminal forms." ${ }^{1}$

\section{Living under the Threat of Deportation}

The vulnerabilities that migrants face occur throughout the migration process. However, once immigrants manage to reach their destination, they live under the threat of these deportation regimes. The fear under these immigration policies changes family and community dynamics. Immigrants and their families become more vulnerable due to the fear of deportation. Immigrant workers do not claim their labor rights and are, therefore, more exposed to labor exploitation. Likewise, families, for fear of leaving their homes, also see their health and education affected negatively. ${ }^{52}$

$4^{8}$ S. Shetty, "Most Dangerous Journey: What Central America Migrants Face When They Try to Cross the Border," Amnesty International, 2014, www.amnestyusa.org/most-dangerous-journeywhat-central-american-migrants-face-when-they-try-to-cross-the-border/.

49 T. Golash-Boza, Deported: Immigrant Policing, Disposable Labor and Global Capitalism (New York: New York University Press, 2015).

5o Shetty, "Most Dangerous Journey."

${ }^{51}$ Van Houtum, "Human Blacklisting: The Global Apartheid of the EU's External Border Regime" at 973 .

${ }^{2}$ S. W. Henderson and C. D. Baily, "Parental Deportation, Families, and Mental Health" (2013) 52(5) Journal of the American Academy of Child and Adolescent Psychiatry 451-453; D. Becerra, 
In Europe, by 2016, the number of unauthorized immigrants peaked at 4 million. Many of these immigrants are refugee asylum seekers who arrived during the immigration crisis in 2015.53 This crisis led to a growing migration emergency in Europe, with an increase in border closures and surveillance of migrants' entry. ${ }^{54}$ This crisis also led to an increasing number of deportations. Some countries have been accused of using racial profiling to identify unauthorized migrants. In the United States, the high numbers of unauthorized migrants (11 million), combined with anti-migrant narratives and restrictive immigration, have created the conditions of possibility for mass deportation.

The approval of the 1996 Antiterrorism and Effective Death Penalty Act and the Illegal Immigration Reform and Immigrant Responsibility Act in the United States facilitated mass deportation by allowing the government to remove individuals without judicial review. According to official statistics in the last three decades, the United States has deported more than 7 million people. Most of these people were men from Latin American countries, revealing raced and gendered patterns in mass deportation. ${ }^{55}$ This deportation regime caused many harmful consequences for individuals, families, and communities. ${ }^{56}$ For example, millions of children have been separated from their parents as a result of deportations. The mass deportation system in the United States is very particular, not only because it expresses specific elements of the apartheid ideology, but also because its laws have historically been racist and discriminatory. Furthermore, the United States deportation system is a paradigmatic case of the negative and unquantifiable consequences for deportees, their families, communities, and the countries to which they have been forced to return. ${ }^{57}$

Multiple sources report that Spain has deported an average of 20 immigrants per day since 2011 (a total of approximately 50,000), most of them Moroccans. Government agencies cite their "irregular" status in the Spanish territory as a reason for expelling migrants..$^{5}$ Meanwhile, France, a country with historically stable

"Anti-Immigration Policies and Fear of Deportation: A Human Rights Issue" (2016) 1(3) Journal of Human Rights and Social Work 109-119.

53 P. Connor and J. S. Passel, "Europe's Unauthorized Immigrant Population Peaks in 2016, Then Levels Off,” Pew Research Center, November 13, 2019, www.pewresearch.org/global/2019/ 11/13/europes-unauthorized-immigrant-population-peaks-in-2o16-then-levels-off/.

54 Ibid.

55 T. Golash-Boza and P. Hondagneu-Sotelo, "Latino Immigrant Men and the Deportation Crisis: A Gendered Racial Removal Program" (2013) 11(3) Latino Studies 271-292.

${ }^{5}$ J. Dreby, "The Modern Deportation Regime and Mexican Families," in C. Menjivar and D. Kanstroom (eds.), Constructing Immigrant "Illegality": Critiques, Experiences, and Responses (New York and Cambridge: Cambridge University Press, 2013), pp. 181-202.

57 M. S. Zatz and N. Rodriguez, Dreams and Nightmares: Immigration Policy, Youth, and Families (Berkeley: University of California Press, 2015).

${ }^{8}$ Redaccion, "Mas de 83.000 inmigrantes deportados de España desde 2011," La Vanguardia, July 23, 2017, www.lavanguardia.com/vida/20170723/4343380857/mas-de-83000-inmigrantesdeportados-de-espana-desde-2on1.html. 
relationships with Spain, has a policy of deporting migrants to regions outside the European Union, but also within it - mostly to Spain. Since no official physical boundaries separate the two nations, activists argue that France selects immigrants for deportation to Spain according to an ethnic profile. Between January and October 2018, France deported almost 10,000 immigrants to Spain. ${ }^{59}$

In Australia, like in the United States and Europe, deportations have also increased in the twenty-first century. Whereas only about 1,000 people were deported a year in the 1980 s, by 2015 , this number had risen to 10,000 per year. At the same time, there were about 13,000 people in immigration detention facilities in Australia in 2014, compared to fewer than 100 in $1990 .{ }^{60}$ Many people deported from Australia during this time were residents who had not returned to their countries of birth in a long time. Immigration enforcement in Australia has thus imposed many mental, social, and economic dilemmas for deported people. ${ }^{61}$

Each of these actions in Europe, the United States, and Australia play a fundamental role in preserving global apartheid. ${ }^{62}$ At the same time, they become binary decision-making mechanisms: to admit entrance through borders or not, to include or to exclude. ${ }^{6} 3$ These actions show how the United States has recently reinforced the apartheid ideology with the border wall construction and everyday antiimmigrant discourses, and how European countries have adopted this doctrine to maintain racial segregation, particularly in its application to people of African and Middle Eastern origin. ${ }^{64}$

\section{The Emergence of a Desperate, Disposable, and Cheap Labor Force}

As a result of these restrictive immigration and deportation regimes, immigrants must choose between their confinement in poor countries and joining a desperate labor force in another country. ${ }^{6}$ This situation turns out to be highly convenient for the global economy, which requires a workforce with these characteristics. These workers are incredibly vulnerable. Employers can easily fire them, cut their salaries and benefits, and prohibit them from forming unions, which precludes the possibility of strikes or negotiating labor standards. In this context, wealthy countries manage

59 M. Gonzalez and M. Martin, "Francia devuelve a España a 1.00o inmigrantes irregulares cada mes," El Pais, November 5, 2018, https:/elpais.com/politica/2018/11/oz/actualidad/1541179682_ 837419.html.

$6 \circ$ J. Walsh, "Report and Deport: Public Vigilance and Migration Policing in Australia" (May 2018) 24(2) Theoretical criminology 276-295.

61 G. Nicholls, Deported: A History of Forced Departures from Australia (Sydney: University of New South Wales Press, 2007).

62 Spener, "El apartheid global, el coyotaje y el discurso de la migracion clandestina."

63 Richmond and Valtonen, "Global Apartheid: Refugees, Racism, and the New World Order."

64 Ibid.

65 H. Walia, "Transient Servitude: Migrant Labour in Canada and the Apartheid of Citizenship" (2010) 52(1) Race \& Class $71-84$ at 72. 
to impose conditions that produce a population of vulnerable laborers. Wealthy countries are aware that, eventually, this workforce will be integrated into global exploitation circuits before and during their migration as well as after deportation. These trends have been reported in countries like Canada and Israel, and in the Latin American region where immigrants with or without work visas are likely to be exploited. ${ }^{66}$ In Latin America, transnational service companies hire people who have been displaced by neoliberal policies or deportation since a substantial part of this population is fluent in the English language and has knowledge of North American culture. ${ }^{67}$

\section{ESTABLISHMENT OF SUBTLE AND RACIST MECHANISMS OF CONTROL, REMOVAL, AND EXPLOITATION OF IMMIGRANTS}

Segregationist ideology can operate through openly racist and exclusionary immigration laws. However, as mentioned at the beginning, the efficacy of these ideologies relies on the ability to recreate themselves in more subtle yet still racist methods of control, removal, or exploitation of migrants. Border closures for humanitarian or political purposes have been established in various regions of the world; detention centers for immigrants have also been part of this new global order. More subtle mechanisms such as "voluntary" return programs have been identified, where migrants are forced to return to their countries of birth regardless of the reasons they immigrated. Finally, and in an even more sophisticated way, temporary work programs in which migrants are invited to work under exploitative conditions have spread around the Global North. ${ }^{68}$

\section{Border Closure for Political, Humanitarian, and Security Reasons}

In 2015, Costa Rica witnessed the arrival of a large number of Cuban and African immigrants who were in transit to the United States; the situation became problematic when the Nicaraguan government decided to close its southern border. As a result, at least 5,000 Cubans and hundreds of Africans became stranded in Costa Rica. Nicaragua justified its actions by arguing that Costa Rica acted irresponsibly by allowing these people to pass through their borders. Nicaragua vigorously defends its territory against threats such as drug trafficking, gangs, and human trafficking. ${ }^{69}$ However, these actions also led to the death of twelve African immigrants, who

66 Willen, Fighting for Dignity: Migrant Lives at Israel's Margins; Walia, "Transient Servitude: Migrant Labour in Canada and the Apartheid of Citizenship” at 72; T. Golash-Boza, "Negative Credentials', 'Foreign-Earned' Capital, and Call Centers: Guatemalan Deportees' Precarious Reintegration" (2016) 20(3-4) Citizenship Studies 326-341.

67 Ibid.

68 Willen, Fighting for Dignity: Migrant Lives at Israel's Margins; Walia, "Transient Servitude: Migrant Labour in Canada and the Apartheid of Citizenship."

69 "Migrantes atrapados en muro de contencion de Nicaragua," Instituto Humanitas Unisionos ADITAL, February 16, 2018, www.ihu.unisinos.br/161-noticias/noticias-espanol/576117-migr antes-atrapados-en-muro-de-contencion-de-nicaragua. 
drowned in 2016 while trying to cross Lake Cocibolca in Nicaragua, in their journey from Costa Rica to the United States. ${ }^{70}$

A similar situation has been suffered by hundreds of thousands of people who were forced to leave Venezuela in recent years due to the country's political crisis. According to the UNHCR, more than 3 million Venezuelans have been forced to flee from Venezuela in 2015. Many crossed the border into neighboring countries, but this unleashed a crisis in the region. In Ecuador, thousands of Venezuelans found themselves stranded when Ecuador decided to close the passage through Rumichaca International Bridge. According to reports, this forced an increase in the undocumented crossing that involved a perilous route for women and minors. International organizations have requested Ecuador to "refrain from actions like closing borders, restricting access for people who might need international protection, punishing irregular entry or presence, requiring official documents like passports and records of past criminal activity, and resorting to immigration detention and hate speech." ${ }^{71}$

In Europe, one typical example is the ongoing conflicts in the Island of Lesvos mentioned previously. These conflicts between countries and regions over migration policy lead to negative consequences for migrants and at the same for the inhabitants in these territories. For Harrison, these new territories of micro apartheid hold a liminal position in the global racial hierarchy, in which countries and regions ally themselves with the dominant White minority. These countries attempt to sandwich themselves "between the 'Civilized White' and the 'Barbarous Black' countries." ${ }^{2}$

\section{"Voluntary" Return Programs Enacted by Racist Ideologies}

In October 2018, the Chilean government set up a Plan of Humanitarian Return to return Haitians living in Chile to Haiti. ${ }^{73}$ Given the reasons Haitians migrate, this voluntary return is more of a punishment than "help" from the Chilean government. ${ }^{74}$ Undocumented Haitians living in the country were invited to sign a document requiring them to leave and not return to Chile for nine years. Scholars labeled these measures as racist due to their singular focus on Haitians - who are nearly all

$7 \circ$ ACAN-EFE, "Sube a siete cifra de migrantes africanos ahogados," El Nuevo Diario, August 2, 2016, www.elnuevodiario.com.ni/nacionales/399925-sube-siete-cifra-migrantes-africanos-ahoga dos-coci/.

${ }^{71}$ Inter-American Commission of Human Rights, "IACHR Concerned about Ecuador's New Measures to Address Forced Migration of Venezuelans," Organization of American States, February 27, 2019, www.oas.org/en/iachr/media_center/PReleases/2019/047.asp.

${ }_{72}$ Harrison, "Global Apartheid, Foreign Policy, and Human Rights" at 56.

73 M. Andrade Moreno, "Programas de retorno voluntario. El caso chileno" (2020) 77(169) Estudios de Derecho 87-117.

74 Ibid. 
Black. ${ }^{75}$ In an interview with Widner Darcelin, spokesman of the Haitian Communities in Chile, he described this allegedly humanitarian program as a deportation program. ${ }^{76}$ Salazar and Ramirez affirm that this program is entirely discriminatory since it fundamentally targets Haitians living under extreme poverty in Chile. ${ }^{77}$ The Chilean government has justified these deportations by arguing that Haitians have not been able to overcome cultural barriers to integrate into Chilean mainstream culture..$^{78}$ According to this report, in the five months since the plan was implemented in October 2018, almost 700 Haitians signed a commitment to "voluntary" return. ${ }^{79}$

Some studies reported how the Israeli government had invited African immigrants to leave the country voluntarily, a policy that follows a similar segregationist logic, where it has offered African immigrants US \$3,000 either to return to Africa or move to another country; if they refuse, they are threatened with the alternative of facing imprisonment. ${ }^{80}$ From the government's perspective, this initiative turns the deportation of temporary or irregular migrants into a voluntary and humanitarian process of leaving the country. It excludes women, children, parents of dependent children, and slavery and human trafficking victims. However, this policy is intended to remove "infiltrating" groups from the territory, which, according to the Israeli government, entered without proper documentation. ${ }^{81}$ Furthermore, the government has initiated an anti-immigrant campaign based on the idea that "migrants might threaten the Jewish character of Israel." ${ }^{\prime 2}$ Although a significant number of these immigrants are fleeing violence and armed conflicts in their home countries, the government has categorized them as economic immigrants rather than refugees.

75 P. K. Sánchez et al., "Haiti, New Immigrant Community in Chile" (2018) 89(2) Revista Chilena de Pediatria 278-283; N. Rojas Pedemonte et al., "Racismo y matrices de 'inclusion' de la migración haitiana en Chile: Elementos conceptuales y contextuales para la discusión" (2015) 42 Polis. Revista Latinoamericana, online: journals.openedition.org/polis/11341.

76 "Comunidades Haitianas denuncian que el Gobierno de Chile realiza "una deportacion encubierta," Sputnik News, November 7, 2018, https://mundo.sputniknews.com/americalatina/201811071083274157-una-deportacion-masiva-de-haitianos/.

77 C. Salazar and N. Ramírez, "El racismo como politica de estado: La deportacion de haitianos en Chile" El Desconcierto, November 7, 2018, www.eldesconcierto.cl/2018/11/o7/el-racismocomo-politica-de-estado-la-deportacion-de-haitianos-en-chile/.

${ }^{78}$ AFP, "Haitianos se acogen a plan de retorno voluntario," Diario Libre, November 4, 2018, www diariolibre.com/actualidad/internacional/18o-haitianos-se-acogen-a-plan-de-retorno-voluntariodesde-chile-JG11179671.

79 Ibid.

8० Y. A. Orgal et al., "Israel's 'Voluntary' Return Policy to Expel Refugees: The Illusion of Choice," in M. Van Risen et al. (eds.), Mobile Africa: Human Trafficking and the Digital Divide (Oxford: African Books Collective, 2019), p. 209.

81 "Israel, African Migrants Told to Leave or Face Imprisonment," BBC News, January 2, 2018, www.bbc.com/news/world-middle-east-42541515.

82 Ibid. 


\section{Free Trade Agreements}

Another strategy for creating a disposable workforce has been through free trade agreements. These pacts create the conditions for thousands of people to lose their jobs in their home countries and force them to migrate without documentation to wealthy countries. Immigrants with undocumented status are easily exploited. In this regard, Harrison states that "this neoliberal regime - in which developed nations aid poorer nations on the condition that they restructure their economies and political systems to accommodate maximum wealth accumulation by multinational corporations - has arrived packaged as so-called free trade." ${ }^{3}$

Walia cites the North American Free Trade Agreement (NAFTA) as an example since it dramatically impoverished many Latin American countries. ${ }^{84}$ In the case of Mexico, more than 15 million people fell into poverty, and more than 1 million were displaced. Many Mexicans were forced to leave their communities, and now work as undocumented immigrants in the agricultural sector of Canada. Willen provides examples of this cheap labor export trend in Israel, as well. The Israeli government recruited workers from Thailand, Romania, Turkey, and China, responding to employers' demands. These workers are very "attractive" since employers presumed these workers are politically neutral. These employers are also attracted by the flexibility in which these workers are hired, meaning there are few labor regulations - making it easier to exploit them. ${ }^{85}$ Willen describes the circumstances in which these movements and hiring processes occur as a form of human trafficking. ${ }^{86}$

These examples show how apartheid ideology operates and how it achieves its objective of racial segregation. ${ }^{87}$ People of color are either forced to remain in their countries of birth or suffer exploitation or even death if they attempt migration in search of better circumstances. These actions show covert racism, whereby governments justify their restrictive migration policies by claiming that immigrants are not capable of integrating and therefore are culturally incompatible with the native culture. In reality, these arguments are an expression of racial intolerance. ${ }^{88}$

\section{Preserving Wealth among a Minority}

The mechanisms discussed help maintain the global apartheid system by eliminating most non-White people from wealthy countries and confining them to much

${ }^{8} 3$ Harrison, "Global Apartheid, Foreign Policy, and Human Rights" at 48.

${ }^{8}$ Walia, "Transient Servitude: Migrant Labour in Canada and the Apartheid of Citizenship" at 72 .

85 Willen, Fighting for Dignity: Migrant Lives at Israel's Margins.

86 Ibid.

${ }^{87}$ Harrison, "Global Apartheid, Foreign Policy, and Human Rights."

88 Fennema, "Populist Parties of the Right." 
poorer nations. Thus, they seek to guarantee that the vast majority of the world's wealth stays in the hands of a White minority.

For scholars like Feagin and Ducey, this form of global organization preserves the power and wealth of Whites by creating an unfair distribution of resources. ${ }^{89}$ According to Titus, the practice of apartheid includes the idea - implicitly assumed or explicitly stated - that a particular group has more rights than others, for example, the presumption that American citizens have a right to access social security while Mexican immigrants do not. ${ }^{\circ}$ Global apartheid involves a strong commitment to protecting and preserving the privileges of White people, which take the form of regulations, immigration laws, and work programs, among other measures. All these mechanisms permit the ideology to operate.

These immigration laws, work programs, and other types of regulations establish racial categories that justify the existence of privileged and unprivileged groups. This ideology separates who belongs to a determined territory and who ought to be removed from it, or conversely, who holds rights and who does not. ${ }^{91}$ At present, there is a concern about the excessive growth of this doctrine, mainly because this ideology resorts to increasingly subtle mechanisms. These practices invigorate racial segregation. ${ }^{92}$ For Feagin and Ducey, this trend is historically rooted in the aggressive exploitation of Native Americans and African slaves. ${ }^{93}$ They argue that White elites have created all possible mechanisms to maintain this social order, from laws to specific institutions. ${ }^{94}$ Although Feagin and Ducey's arguments apply primarily to the United States, these same ideologies can be found worldwide.

\section{CONCLUSIONS}

Today's model of global apartheid has shaped migratory policies globally. The rise of highly popular extreme right-wing parties in Europe and anti-immigrant discourses throughout the settler colonial states of the United States, Canada, Israel, and Australia are evidence of the consolidation and spread of this ideology. ${ }^{95}$ In addition, we have seen increased evidence of micro apartheids, which configure segregation at a smaller scale and in a more subtle manner. ${ }^{96}$ Cases of policies in Israel, Chile, and Ecuador that limit human mobility and institute racial segregation are some examples of this broader tendency.

${ }^{89}$ Feagin and Ducey, Racist America: Roots, Current Realities, and Future Reparations.

$9 \circ$ A. Titus, Unravelling Global Apartheid: An Overview of World Politics (Cambridge: Polity Press, 1996).

$9^{1}$ Omi and Winant, Racial Formation in the United States.

$9^{2}$ Harrison, "Global Apartheid, Foreign Policy, and Human Rights."

93 Feagin and Ducey, Racist America: Roots, Current Realities, and Future Reparations.

94 Ibid.

95 Van Houtum, "Human Blacklisting: The Global Apartheid of the EU's External Border Regime."

${ }_{96}$ Harrison, "Global Apartheid, Foreign Policy, and Human Rights." 
Restrictions on immigration at the global and local levels reflect how the global apartheid ideology enacts and justifies its goals through a wide range of discursive tropes and mechanisms, grounded in new racism. The specifications of this process are the programs of temporary work, voluntary return programs, and an overwhelming number of requirements for legal migration. These measures all severely restrict the possibility of poor people of color around the world - limiting their options to improve their living conditions.

The core problem with this ideology is the idea that some groups deserve rights while others do not based on the place of birth. ${ }^{97}$ During the apartheid regime in South Africa, resource distribution followed racial boundaries. Under global apartheid, privileges and resources are allocated based on national origin, which creates a racialized divide between Europe and Africa and between the United States and Latin America.

97 Van Houtum, "Human Blacklisting: The Global Apartheid of the EU's External Border Regime." 